\title{
横断歩道橋の支柱に生じたき裂損傷の 原因調査と対策
}

\author{
三木 千壽 1 - 小野 潔 2 横山 功一 ${ }^{3} \cdot$ 原田 $\quad$ 隆郎 ${ }^{4}$ \\ 1フェロー 東京工業大学教授 大学院理工学研究科土木工学専攻 (†152-8552 東京都目黒区大岡山2-12-1) \\ E-mail:miki@cv.titech.ac.jp \\ 2正会員 東京工業大学准教授 大学院理工学研究科土木工学専攻（同上） \\ E-mail:ono.k.ae@m.titech.ac.jp \\ 3フェロー 茨城大学教授 工学部都市システム工学科 (广316-8511 茨城県日立市中成沢町4-12-1) \\ E-mail:yokoyama@mx.ibaraki.ac.jp \\ 2正会員 茨城大学准教授 工学部都市システム工学科（同上） \\ E-mail:harada@mx.ibaraki.ac.jp
}

\begin{abstract}
地方道を跨ぐ横断歩道橋の支柱で，支柱の全周の約半分に達する大きなき裂損傷が発見された. 横断歩 道橋でこのような重度のき裂損傷が報告された例は著者らの知る限りない. 日本の横断歩道橋は昭和 40 年 代に飛躍的に整備されたが, 標準設計を適用して設計・施工された横断歩道橋も多い. よって, 今回, 重 度のきれつ損傷が発見された横断歩道橋の鋼管支柱と同様の構造細目を有する横断歩道橋も存在し, 同様 の重度の損傷が発生する危険性もあるため, その原因を解明することは, 同種の損傷を未然に防ぐ意味で 非常に重要である.

そこで, 本論文では, 破面観察, 材料試験, 応力測定等を行って損傷の発生原因調査, メカニズムの推 測を行うとともに，き裂損傷の補強等の対策も行ったので報告するものである.
\end{abstract}

Key Words : pedestrian bridge, fracture, cause identification, retrofit

\section{1. はじめに}

地方道を跨ぐ横断歩道橋において，横断歩道橋を支 える鋼管でできた2本の支柱のうち，1本の支柱でき裂損 傷が発見された. その損傷は，鋼管全周の約半分にわた る貫通き裂損傷であった．我が国の鋼道路橋および鋼鉄 道橋における疲労損傷1,2), 3) 4), 兵庫県南部地震における 港湾幹線道路の鋼製橋脚隅角部のき裂損傷)等，道路橋 および鉄道橋ではこのような重大な損傷が報告された例 はある. しかし，横断歩道橋については，著者らの知る 限りこのような大きなき裂損傷が報告された例はない．

我が国の道路にかかる横断歩道橋は, 昭和34年に愛知 県西枇把町の旧国道22号に設置されたのが最初である?. その後, 昭和 40 年代に入り, 当時の交通事故の急激な増 大に対処するため，立体横断施設が有力な交通事故防止 の手段として取り上げられるようになったの?. 特に昭和 40年代には飛躍的にその整備が図られ，平成19年4月1日 現在, 日本の道路にかかる横断歩道橋の数は11,406橋と なっているか. 横断歩道橋の設計・製作の基準としては,
横断歩道橋設計（参考設計）指針解説 ${ }^{8)}$ ，立体横断施設 技術基準・同解説”)が存在する. これら基準の他，特に 昭和 40 年代の急速な横断歩道橋の設置に対処するため, 横断歩道橋設計図集 ${ }^{10}$, , 土木構造物標準設計 $\mathrm{V}$ (横断歩 道橋） ${ }^{11}$ ，横断歩道橋便覧 ${ }^{12)}$ （以下，10）～12)を「標準 設計等」という）が出版された. この標準設計等では, 工期の短縮，工費の節減，業務の簡素化を図るため，標 準的な構造, 構造細目等が示されており, 多くの横断歩 道橋が標準設計等に基づき，設計，製作された ${ }^{12}$ ，今回 き裂損傷が発見された横断歩道橋も, 標準設計等により 設計・施工されていた. よって, 損傷が発見された横断 歩道橋と同様の構造細目を有する横断歩道橋は他にも存 在し，今回発見されたような重大なき裂損傷が発生する 危険性が考えられる. 同様な重大な損傷を未然に防ぐに は, 損傷の原因, メカニズムを解明し，必要に応じて対 策を講じることが重要となってくる.

そこで, 本論文では, 破面観察, 損傷が発見された 支柱から切り出した試験片による材料試験, 支柱に発生 寸る応力測定等を行い, き裂損傷の発生原因照査, メカ 


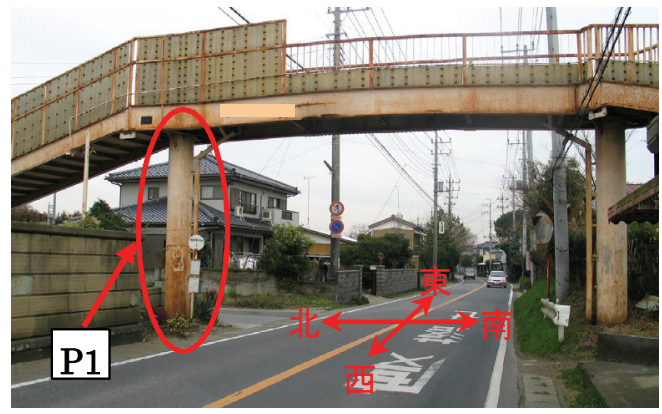

写真-1 横断歩道橋の外観（西面）

ニズムの推測を行うとともに，き裂損傷に対する補強等 の対策を行ったので報告する.

\section{2. 横断歩道橋の概要}

き裂損傷の発見された横断歩道橋の外観を写真-1に, 側面図を図-1に示寸，図-1に示寸ように，本横断歩道橋 は，支間長 $10.5 \mathrm{~m}$ ，桁下高さ $4.7 \mathrm{~m} の$ 上部構造を2本の609.6 $\phi$ の鋼管で支える構造となっており，1971年に完成して いる．609.6 фの支柱は，標準設計等において，主げた 用1本柱の場合の支柱として採用されている. また，標 準設計等の鋼管の規格としては，一般用構造用炭素鋼鋼 管STK41が示されていることから，損傷の発生した本横 断歩道橋の支柱には，609.6 $\phi$ のSTK41が使用されている と推測される.

なお，横断歩道橋の近くには，中学校および小学校が 存在し, 中学校および小学校の生徒を含む約100名が通 学時に利用している.

\section{3. 損傷の外観および破面観察}

き裂の発生・進展状況，破壊起点部およひ破壊形態を 確認, き裂の発生原因を調査寸るため, き裂の発生した P1支柱（写真-1, 図-1参照）のき裂損傷の外観調査, 破 面観察を行った．さらに，き裂発生原因調査のため，P2 支柱（図-1参照）および上部構造の損傷についても外観 調查等を行った.

\section{(1) 外観調査}

\section{a) P1支柱}

鋼管支柱の全周の約半分にもおよぶき裂は，横断歩道 橋を支える2本の支柱のうち，写真-1および図-1に示す

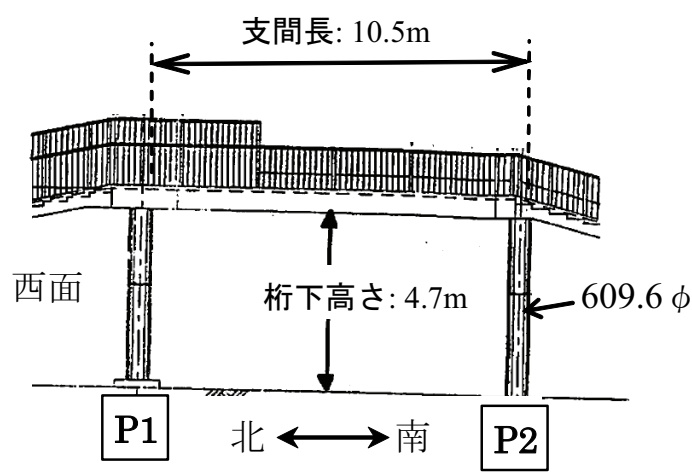

図-1 横断歩道橋の側面図（西面）

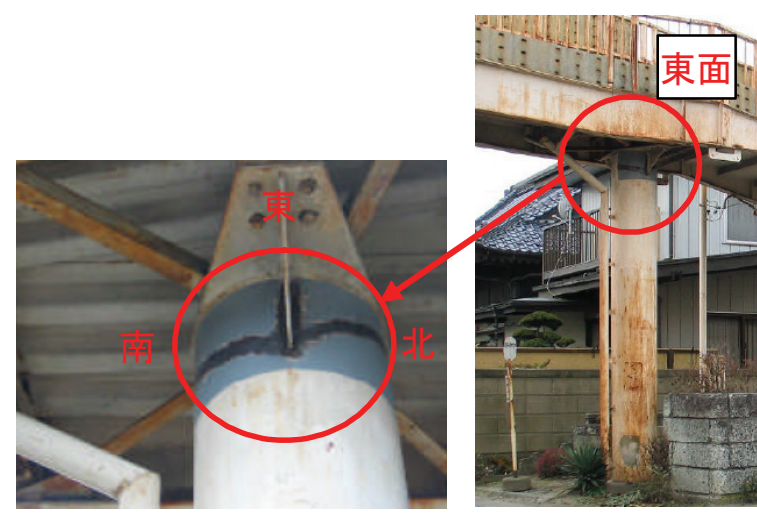

写真-2 き裂損傷の位置

P1支柱で発見された。 P1支柱で発見されたき裂の位置を 写真-2に示寸．き裂は，南一東一北側の鋼管の約半周に およぶ貫通き裂であった。

写真-3(a)にP1支柱の東面に取り付けられたリブ（以 下，「P1-東リブ」という）先端付近の, 写真-3 (c) にP1 支柱の西面に取り付けられたリブ（以下，「P1-西リ ブ」という) 先端付近の, 溶接の状況, 磁粉探傷結果等 をそれぞれ示す．写真-3(a)および写真-3(c)より，P1-東 リブおよびP1-西リブのいずれのリブ先端付近において も，リューダス帯が観察された．さらに，いずれのまわ し溶接部付近においても，き裂が観察され，リブ先端の まわし溶接と側面のすみ肉溶接が連続しておらず，溶接 サイズも小さいことがわかる。また，まわし溶接部のビ ード形状は，リブ取付け溶接の一般部のビード形状と明 かに異なっており，この部分のみ後から溶接を行ったと 推測される．なお，写真からはわかりにくいが，溶接終 端に生じるクレーターも観察された. 


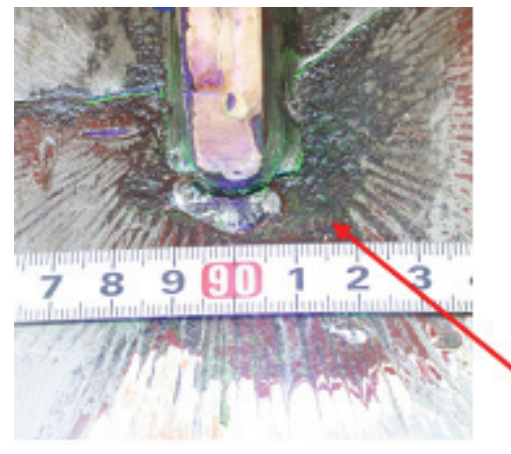

(a) P1-東リブのまわし溶接部

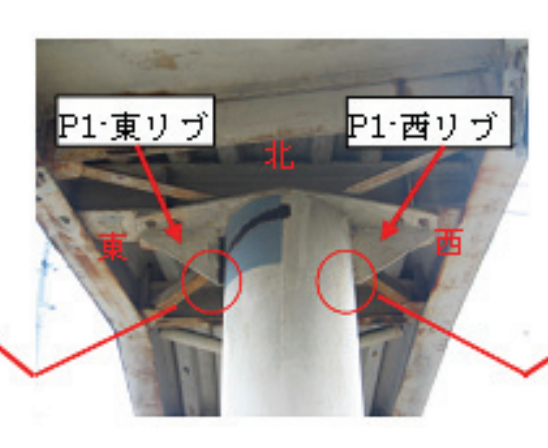

(b) リブの位置

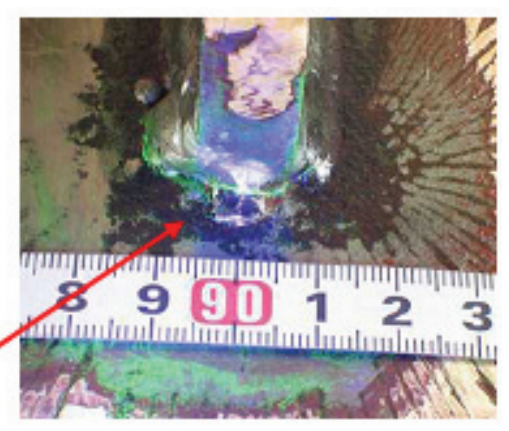

(c) P1-西リブのまわし溶接部

写真-3 P1支柱のリブのまわし溶接部付近の状況

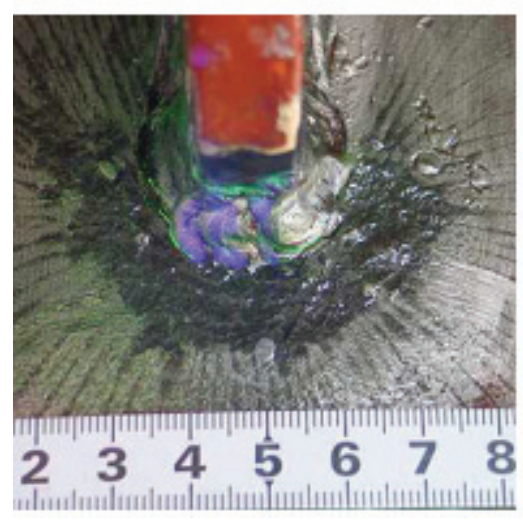

(a) 東リブ

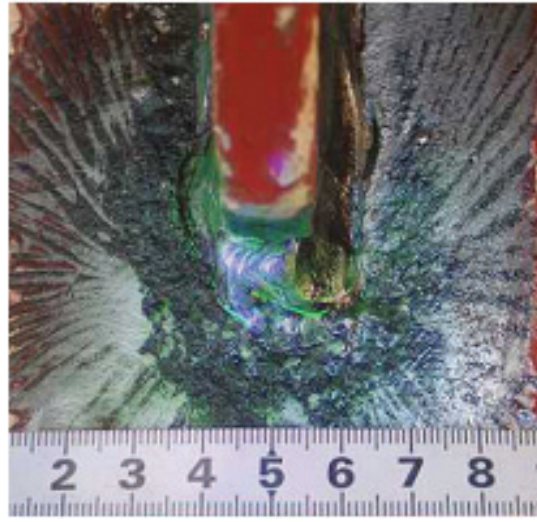

(b) 西リブ

写真-4 P2 支柱のリブのまわし溶接部付近の状況

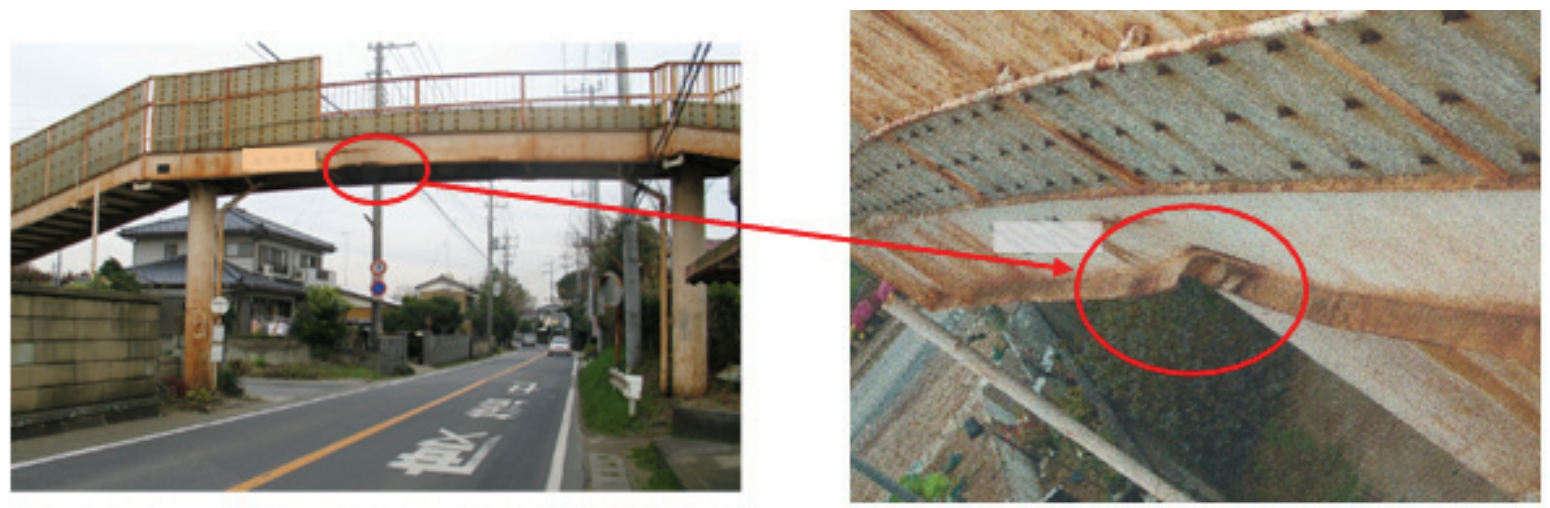

写真-5上部構造鋼桁の損傷（変形）（西面）

\section{b) P2支柱}

写真-4に，P2支柱の東面および西面のリブの先端付近 の溶接の状況，磁粉探傷結果等を示す. P1支柱と同様, P2支柱にもリューダス帯が観察されるが，P1支柱のよう なき裂は見あたらない. 溶接状況については，リブ側面 のすみ肉溶接とまわし溶接の不連続は見受けられず，ま わし溶接部の溶接サイズもP1支柱に比べて大きいことが わかる。

\section{c) 上部構造}

写真-5に西面の上部構造の鋼析部の損傷例を示す．写
真に示すように，上部構造の鋼栴の下フランジが変形し て損傷していることがわかる.この損傷位置は，ちょう ど車両の走行位置 (左側車線) と一致している. 上部構 造の桁下のクリアランスが4.7m（図-1参照）であること を考慮すると, 車両ではなく, 車両の積み荷等が鋼桁に 衝突して発生したものであると推測される. 同様の変形 は反対側の東面の鋼桁下フランジにも生じており, 一部, 変形による損傷を補修した箇所も存在した.

よって，写真-3のリューダス帯，写真-5の変形をあ わせて考えると, 車両の積み荷等が横断歩道橋上部構造 

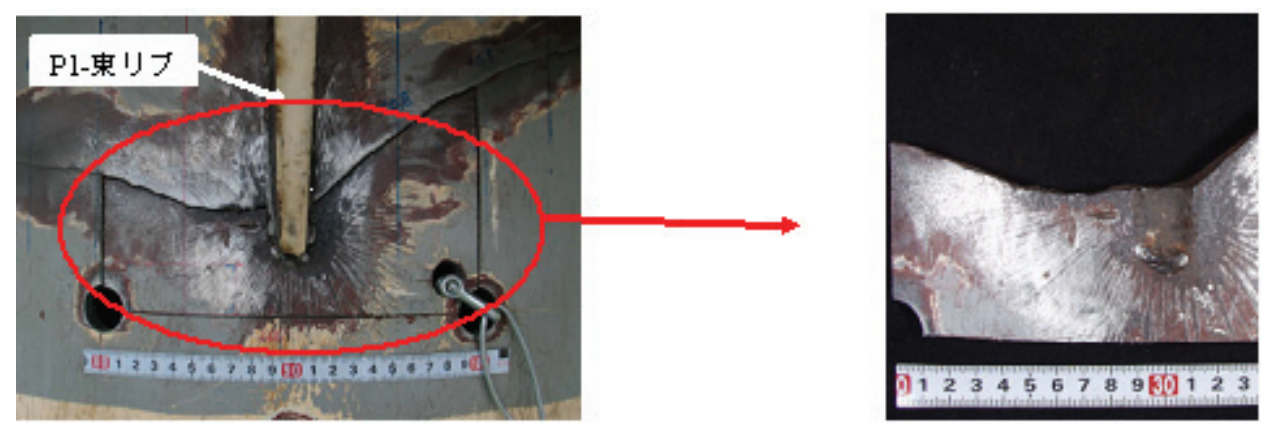

写真-6 き裂破面を含む試料の切り出し
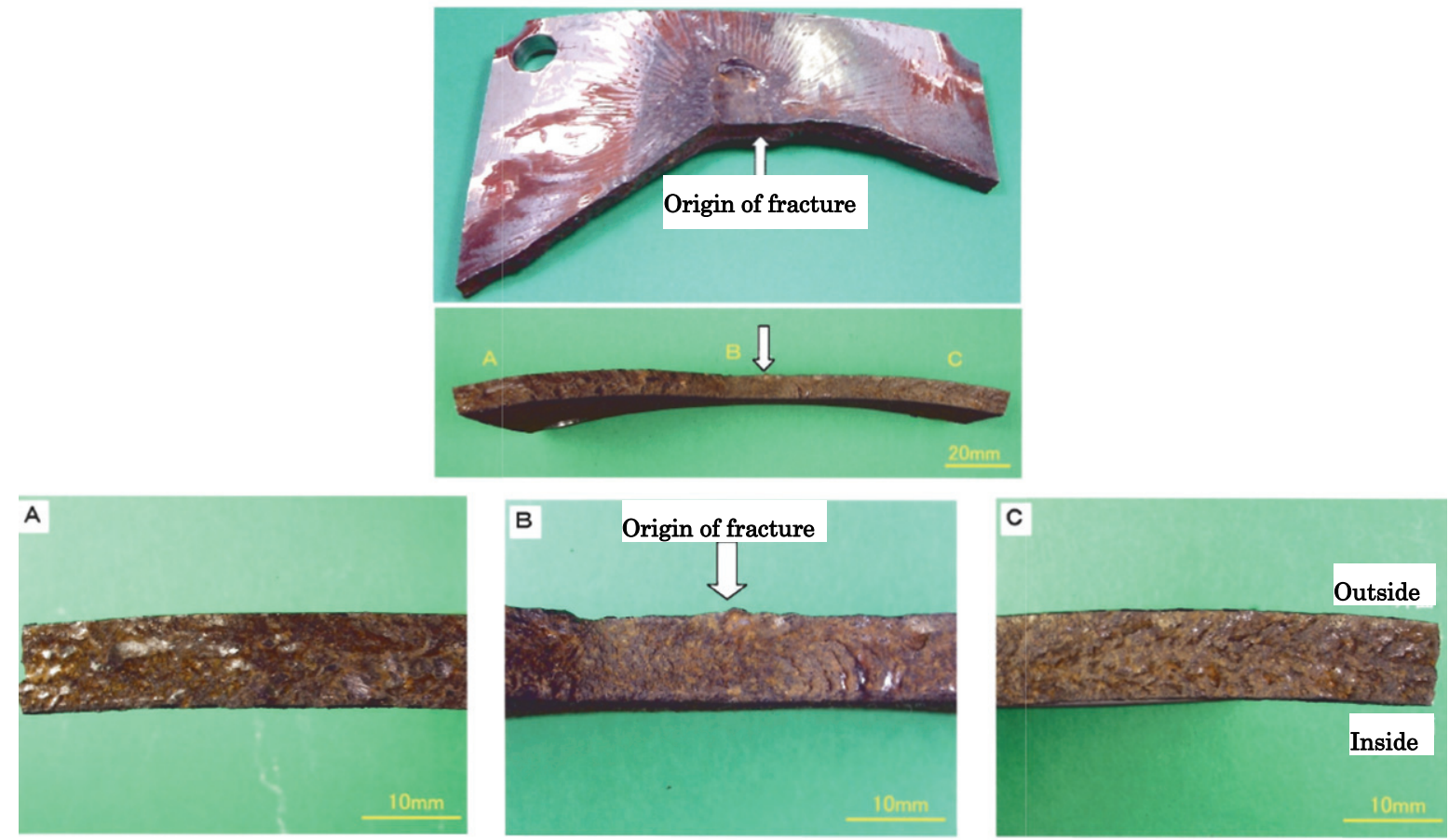

写真-7 き裂破面の外観観察

の鋼林に衝突したことにより，き裂損傷が発見されたP1 支柱は大きな衝撃力を受けた可能性が示唆される．ただ し，通常の品質の鋼材の溶接部を起点としてこのような 衝撃力によって脆性破壊が発生する可能性は低く，発生 原因を特定するために以降の詳細な調査を実施した。 ま た，以下の3. (2) a)に示すように，き裂の起点が発生応 力の最大となるリブ先端ではないことも疑問点である.

\section{(2) 破面観察}

P1支柱からき裂破面を含む試験片を取り出し，目視お よび走查型電子顕微鏡(SEM)により，P1-東リブおよび P1-西リブに発生したき裂の破面観察を行った.

\section{a) P1-東リブ}

破面観察を行うため，写真一に示寸ように，き裂破面 を含む試料を切り出した. 写真-7に破面の状況を示寸. き裂の起点はリブ先端から約 $20 \mathrm{~mm}$ 離れた位置の寸み肉
溶接部であり，その止端からであるかルートからである かは不明である.この位置からリブ先端に向かっての寸 み肉溶接はフラットな破面で切断されている. 溶け込み が極めて悪いが，この破断の原因が，溶接割れか疲労か は不明である。

溶接破面は錆で覆われ破面模様が明瞭ではないが，破 面に沿って斜めに切り出した両端の部分（写真-7の $「 \mathrm{~A} 」 と 「 \mathrm{C} 」$ 部分）には, 山形模様が観察され，そ の方向から破壊は試料中央部から両端に向かって進展し たと考えられる．写真-7の「B」に示寸中央平坦等を観 察寸ると, 外面から内面に向かって広がった放射状模様 が観察され，破壊起点は外面側と判断される．その放射 状模様の収斂点は, 破壊面に向かって右側の溶接ビード 近傍であり，破壊起点はすみ肉溶接部と推定される。

次に, 破面の詳細な調查を行うため, 走查型電子顕微 鏡(SEM)を用いた観察を行ったＳSEM観察を行うに際し， 


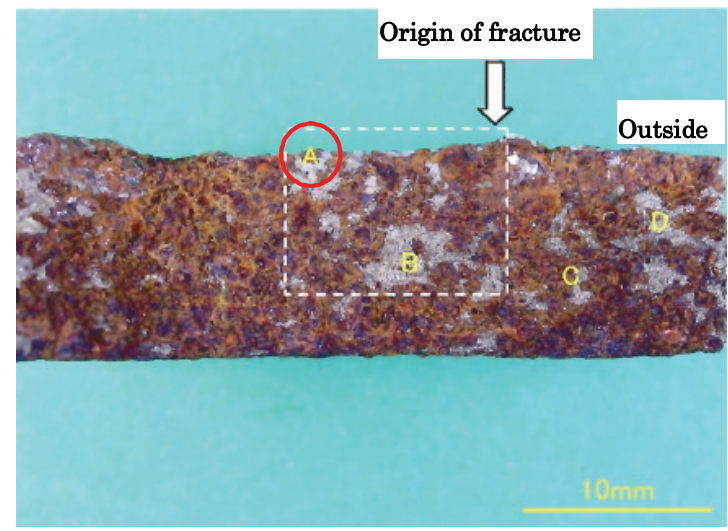

(a) SEM観察を行った箇所

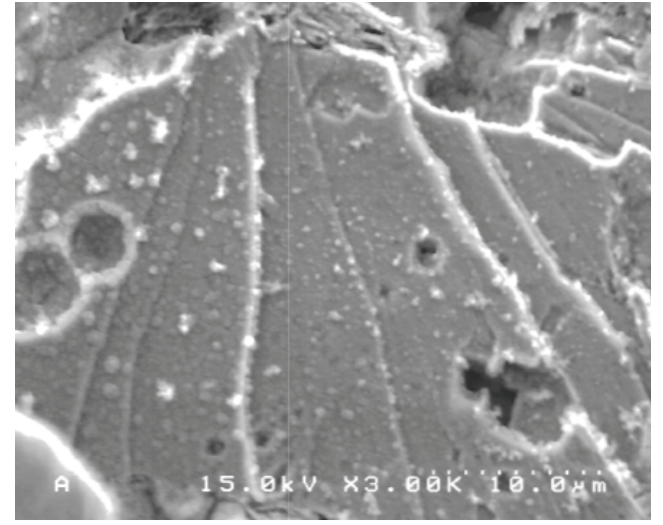

(b)「A」部分のSEM観察結果

写真-8 SEM観察結果

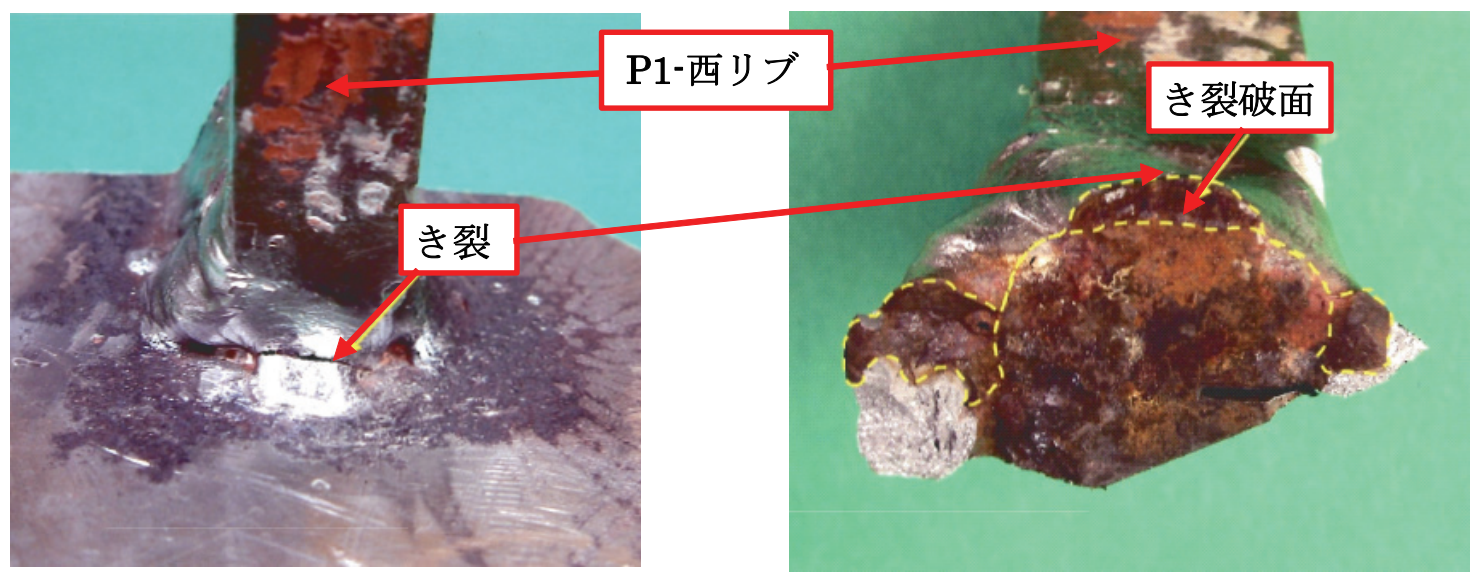

(a) P1-西リブのまわし溶接部

(b) 暴露させたき裂破面

写真-9 き裂破面の外観観察

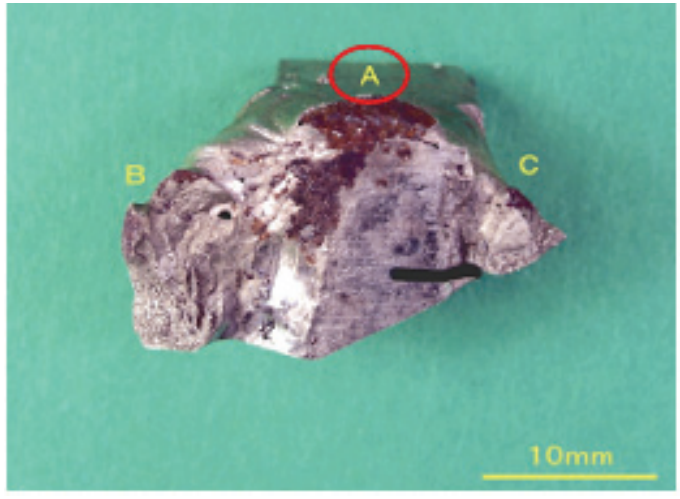

(a) SEM観察を行った箇所

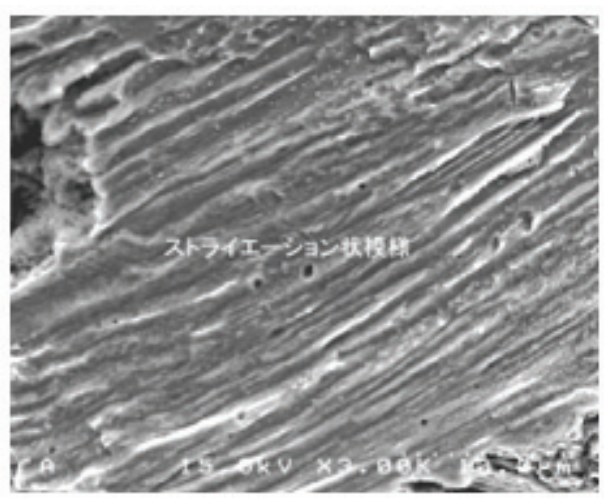

(b)「A」部分のSEM観察結果

写真-10 SEM観察結果

破面を覆う錆を除去するため，希塩酸およびインヒビタ 一溶液中で超音波洗浄を実施した。写真-8に洗浄後の破 面および「A」部分のSEM観察結果（倍率：3,000倍）を 示す．錆の進行が激しかったため，破面形態はほとんど 残存していなかった. しかし，一部残存した破面には， 写真-8(b) に示すように，リバーパターンが明瞭に観察 され，へき開割れした脆性破面であると判断される。な お，写真-8(a)の「B」，「C」および「D」の部分の
SEM観察結果でも，「A」の部分と同様，へき開割れし た脆性破面が観察された。

\section{b) P1-西リブ}

破面観察を行うため，き裂を含む試料を支柱から切り 出し（写真-9(a)），まわし溶接部を液体窒素に侵漬し た後，衝撃を加えて破面を露呈させた（写真-9(b)）. き裂破面の錆が著しく，破面部の特性に曖昧さが残る部 分もあるが，未溶着部が存在することが推測される. 
表-1 化学成分分析結果

\begin{tabular}{|c||c|c|c|c|c|}
\hline & $\begin{array}{c}\mathrm{C} \\
(\%)\end{array}$ & $\begin{array}{c}\mathrm{Si} \\
(\%)\end{array}$ & $\begin{array}{c}\mathrm{Mn} \\
(\%)\end{array}$ & $\begin{array}{c}\mathrm{P} \\
(\%)\end{array}$ & $\begin{array}{c}\mathrm{S} \\
(\%)\end{array}$ \\
\hline \hline 鋼管母材 & 0.20 & 0.009 & 0.49 & 0.010 & 0.015 \\
\hline SS41 (JIS) & - & - & - & $<0.050$ & $<0.050$ \\
\hline STK41 (JIS) & $<0.25$ & - & - & $<0.040$ & $<0.040$ \\
\hline
\end{tabular}

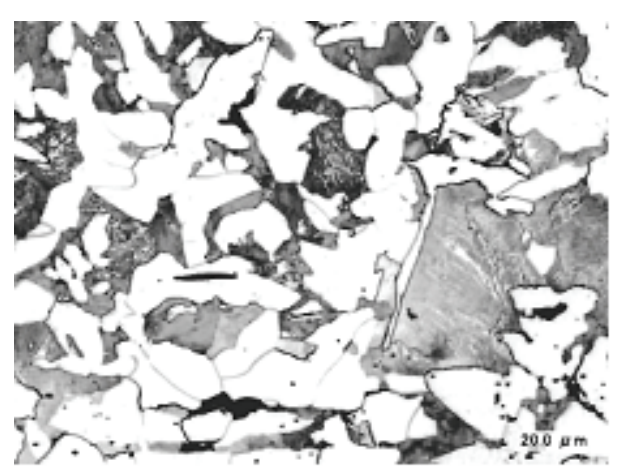

写真-11 組織の観察結果

また，P1-東リブと同様，希塩酸およびインヒビター 溶液中で超音波洗浄を実施した後, SEM観察を行った.

写真-10に洗浄後の破面,「A」の部分のSEM観察結果 （倍率：3,000倍）を示す. 写真-10 (a) に示すように, 「A」の部分は洗浄後も錆が強固に付着しており，最初 に割れた部分であることが示唆される．また，強固な錆 が付着している関係で，破面の大半は原破面が存在しな いが，一箇所だけストライエーション模様が観察され

(写真-10(b))，当該箇所の破面は疲労破面であると推 測される。なお，写真-10(a)の「B」，「C」および

$\lceil\mathrm{D}\rfloor の$ 部分のSEM観察結果でも，「A」の部分と同様, ストライエーション模様が観察された. したがって, 溶 接部に疲労き裂が発生し, それが脆性破壊の起点となっ た可能性が高い.

\section{4. 材料試験}

標準設計等の規定から推測すると，き裂が生じたP1橋 脚はSTK41を使って製作されたと考えられる.しかし， 本横断歩道橋は完成後30年以上経過していることもあり, 現存した当時の設計資料は十分ではなく，材料特性に関 する詳細な情報は見つからなかった。そこで，き裂の発 見されたP1支柱の鋼管の材料特性を把握するため，P1支 柱の鋼管母材部から試料および試験片を作成し，化学成 分分析，組織観察，ビッカース硬さ試験，シャルピー衝 撃試験を実施した.

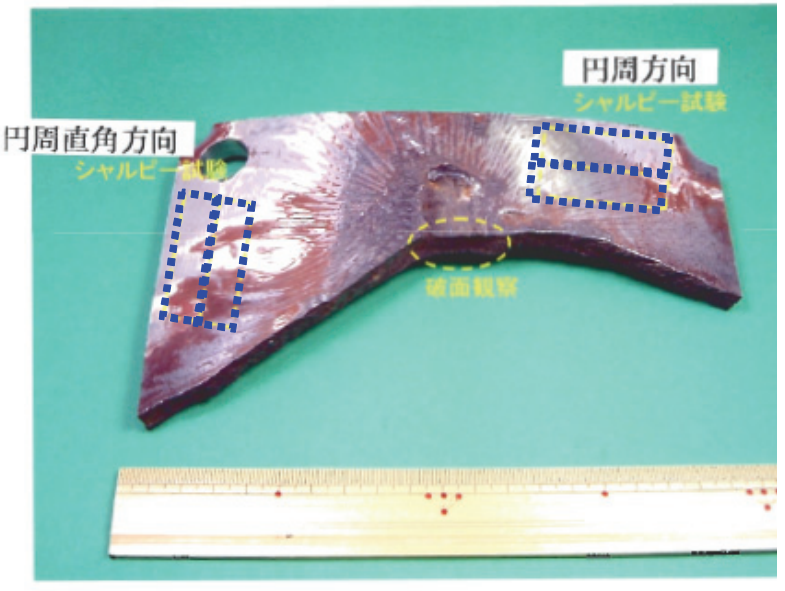

写真-12 シャルピー衝撃試験片の切出し位置

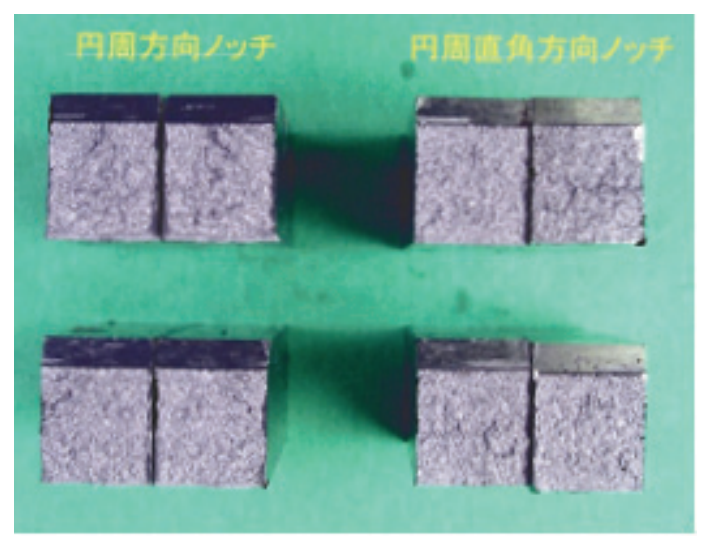

写真-13 試験後の破面

表-2 シャルピー衝撃試験結果

\begin{tabular}{|c||c|c|}
\hline \multicolumn{1}{c||}{} & $\begin{array}{c}\text { 吸収エネルギー } \\
(\mathrm{J})\end{array}$ & $\begin{array}{c}\text { 脆性破面率 } \\
(\%)\end{array}$ \\
\hline \hline 円周方向 & 10 & 95 \\
\hline 平均値 & 6 & 95 \\
\hline 円周直角方向 & 8 & 95 \\
\cline { 2 - 3 } & 4 & 100 \\
\hline 平均値 & 6 & 100 \\
\hline
\end{tabular}

\section{(1) 化学成分分析}

P1支柱の鋼管母材の化学成分分析結果等を表-1に示す. 表-1の下2段には，当時のJSに規定されるSS41および STK41の化学成分を示す. なお，表-1中のCおよびSにつ いては，然焼赤外線吸収法により，それ以外の元素につ いては，スパーク放電発光分光分析法により分析を行っ た．表-1より，き裂の発生したP1支柱に使われている鋼 管は当時のSTK41の化学成分の規定を満足していること がわかる。 


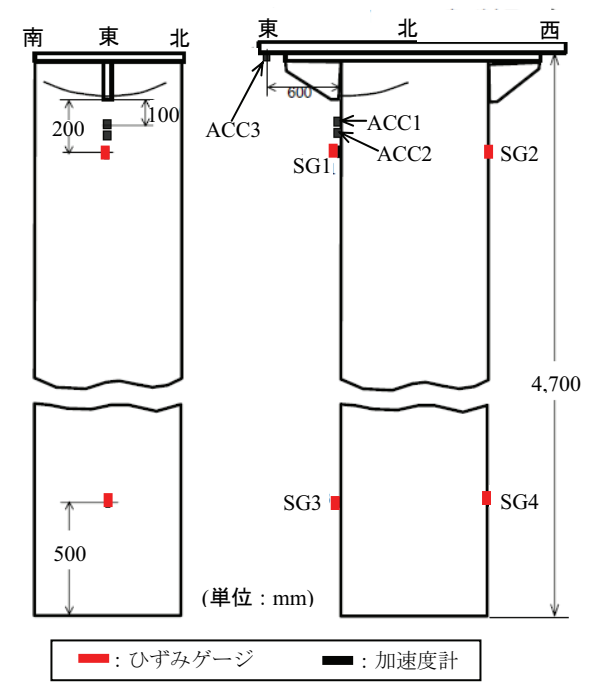

図-2 加速時計・ひずみゲージ配置図（P1 支柱）

\section{(2) 組織観察}

支柱母材の組織観察は，P1支柱から取り出した試料を 表面研磨した後，ナイタール（3\%硝酸エタノール）で エッチングを行い, 光学顕微鏡により行った. 写真-11 にその結果（倍率：500倍）を示す．写真-11より，支柱 母材のミクロ組織はフェライト相とパーライト相の混在 する組織となっていることがわかる．また，この組織は， STK41の素材であるSS41の一般的な成分規格に合致して いる.

\section{(3) ビッカース硬さ試験}

試験力19.61Nでビッカース硬さ試験を行った。試験か ら求まったビッカース硬さは，158HVである．ビッカー ス硬さから換算される近似引張り強さは約510MPaであ り, 当時のJISに規定されるSS41材の引張り強度 $\left(41 \mathrm{~kg} / \mathrm{mm}^{2} \sim 52 \mathrm{~kg} / \mathrm{mm}^{2}\right)$ を満足している.

\section{(4) シャルピ一衝撃試験}

写真-12の青い点線で示すように，P1支柱の鋼管の円 周方向および円周直角方向から，それぞれ2本ずつ試験 片を採取した。ただし，鋼管の寸法の関係で，標準試験 片が採取出来なかったことから，サブサイズ試験片を採 取した. そして，そのサブサイズの試験片を用いて試験

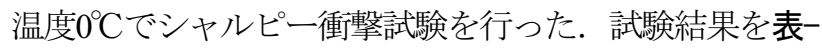
2に，試験後の試験片の破面を写真-13に示す．表-2より， シャルピー吸収エネルギーの平均值は円周方向で8J, 円 周直角方向で5Jであった。 また，写真-13の破面から求 められる脆性破面率は円周方向で $95 \%$, 円周直角方向で 100\%であった。これらのことから，損傷の生じた支柱 に使われている鋼管は非常に衝撃吸収エネルギーが低く，
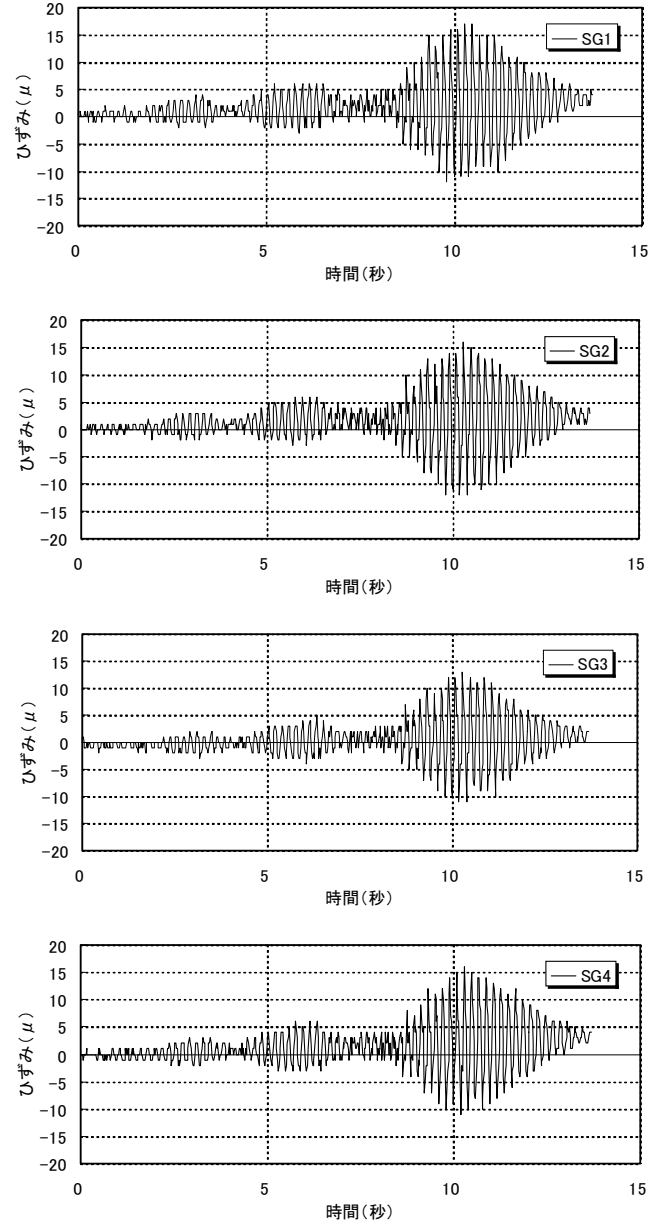

図-3 ひずみの応答值
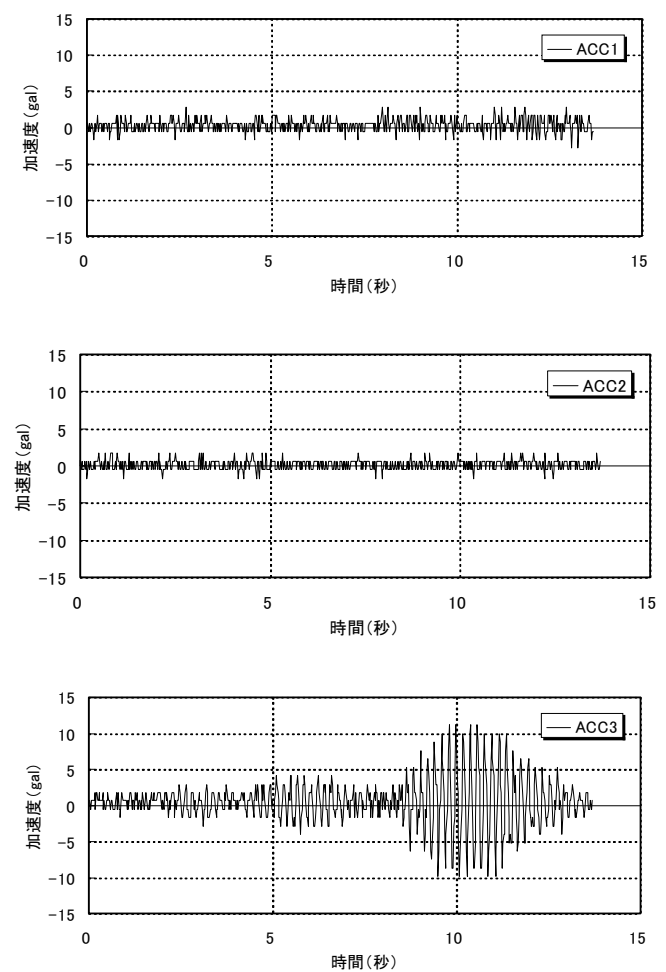

図-4 加速度の応答值 


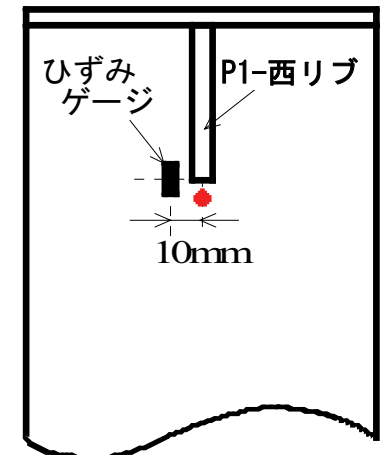

図-5 ゲージの配置位置 (P1支柱)

衝撃に弱いもので言える.

\section{5. 応力測定}

横断歩道橋を利用する歩行者, 横断歩道橋が跨ぐ道路 を走行する車両, 風等により, 横断歩道橋を構成する部 材に応力が発生する. 今回, き裂損傷の発見されたP1東リブと反対側のP1-西リブのまわし溶接部では，写真一 10 (b) に示寸疲労破面が観察された。支柱とP1-西リブを 接合している溶接品質の悪さも関係し，人の歩行および 車両の通過，風等によって支柱に発生する応力により， 疲労破面が生じた可能性がある，そこで，走行車両およ び人の歩行・走行による横断歩道橋の全体挙動の把握を 行った後, 車両通過時および幾つかの人の歩行・走行パ ターンでP1-西リブのまわし溶接部付近に発生する応力 の測定を行った．その測定結果を基に，発生応力と走行 車両および人の歩行・走行状態との関係について調查を 行うとともに，応力範囲およびその頻度を求めた.

\section{(1) 横断歩道橋の全体挙動}

図-2に示寸位置に加速度計（ACC1，ACC2，ACC3）， ひずみゲージ（SG1，SG2，SG3，SG4）を設置し，車両 および歩行者によって発生する加速度およびひずみの応 答值を基に，横断歩道橋の全体挙動の把握を行った。 な お，ACC1からは水平方向の加速度，ACC2およびACC3 からは鉛直方向の加速度，SG1〜SG4からは支柱の円周 直角（高さ）方向のひずみをそれぞれ測定した.

1台のトラックが横断歩道橋の下を通過した時のSG1 〜SG4のひずみ応答およびACC1〜ACC3の加速度応答を， それぞれ図-3および図-4に示す，なお，トラックは荷重 が既知のテスト用のトラックではなく，当該地方道を走 行していた一般のトラックである. 図-3より，トラック の通過によりSG1〜SG4で測定されるひずみは，いずれ も振幅および位相がほぼ等しいことがわかる。よって, P1-東リブの存在する東面，P1-西リブの存在する西面に 発生する応力に対しては，曲げモーメントの影響は小さ

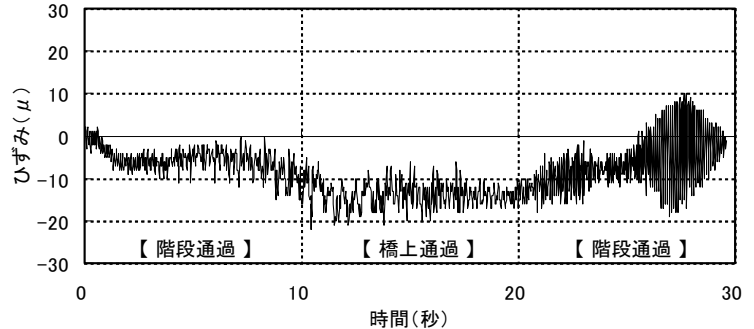

(a) 歩行

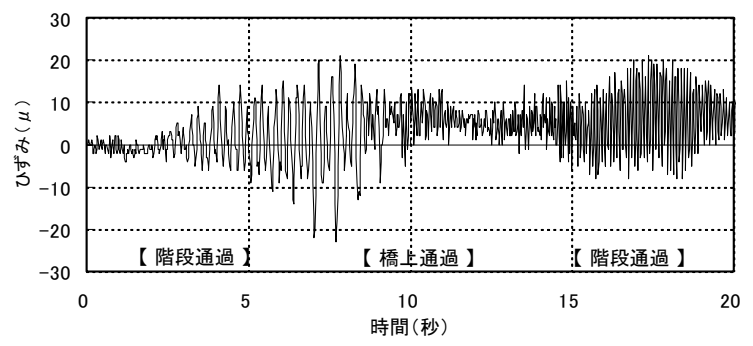

(b) 走行

図-6 1名の人によるひずみ応答

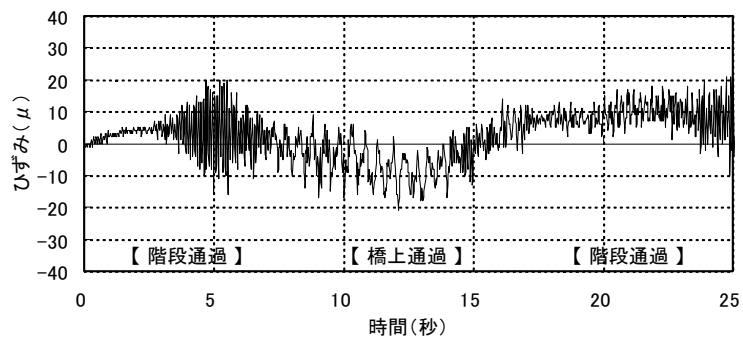

(a) 歩行

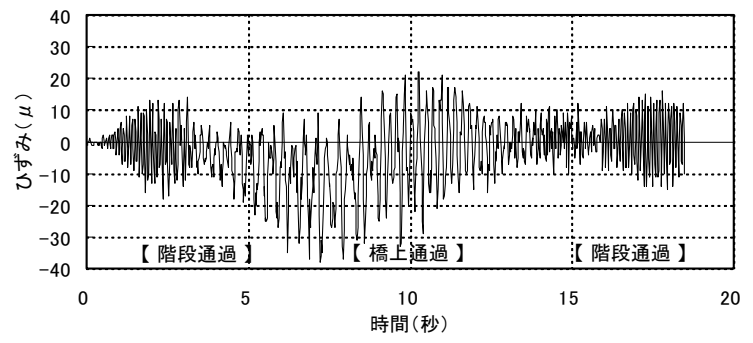

(b) 走行

図-7３名の人によるひずみ応答

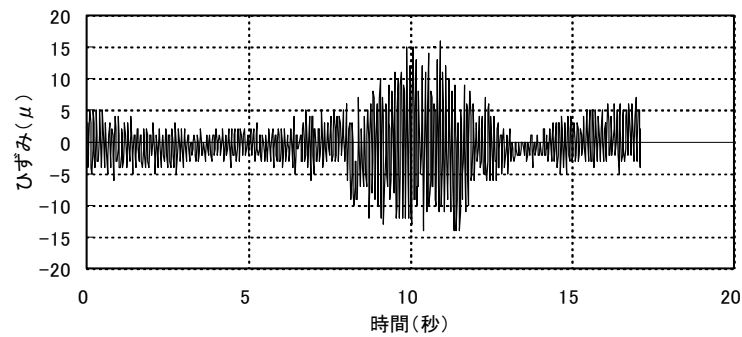

図-8 トラックの走行によるひずみ応答

く，軸力が支配的であることがわかる．また，図-5より， 加速度の大きさは $\mathrm{ACC} 3>\mathrm{ACCl}>\mathrm{ACC} 2$ となっており，上 


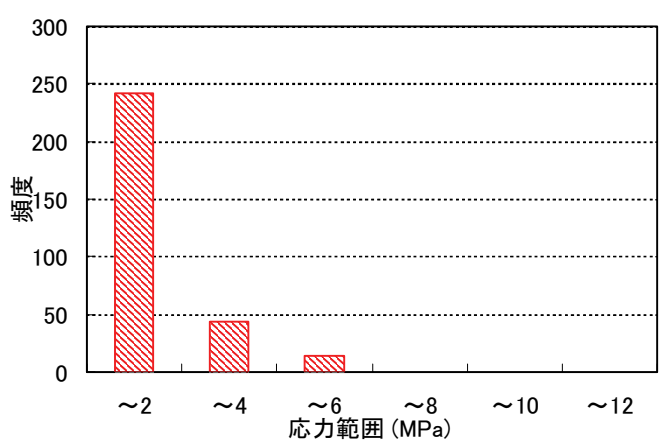

(a) 歩行

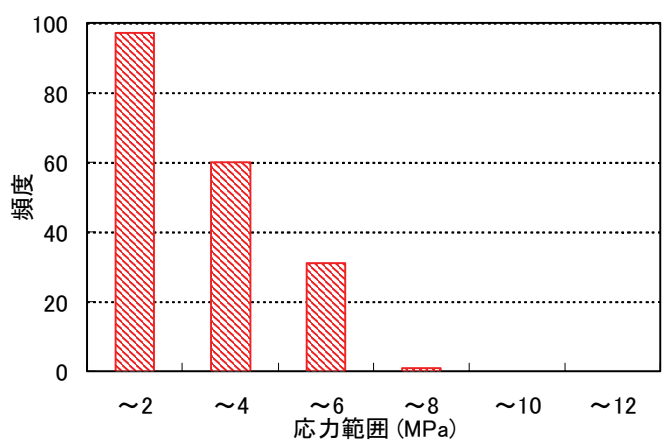

(b) 走行

図-9 1名の人による応力範囲頻度分布

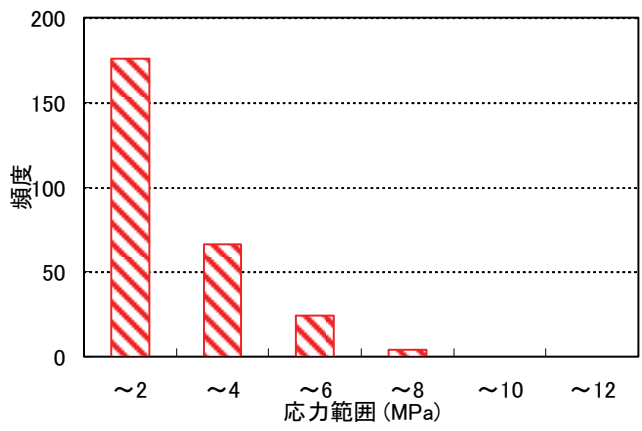

(a) 歩行

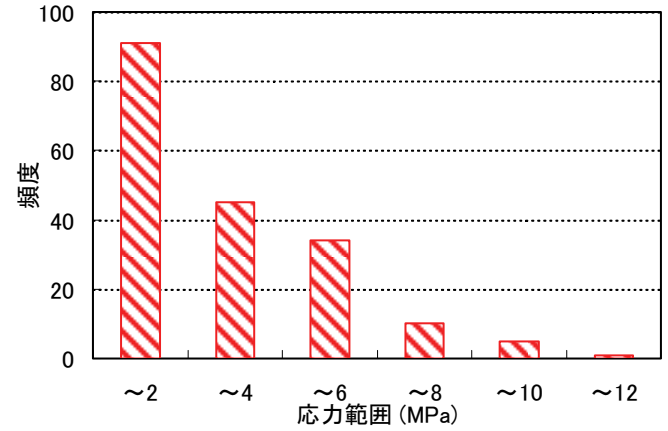

(b) 走行

図-10 3名の人による応力範囲頻度分布

部構造の鉛直加速度が最も大きく, $\mathrm{P} 1$ 支柱の水平方向の 加速度が最も小さいことがわかる。 なお，人が横断歩 道橋を歩行および走行した場合のひずみおよび加速度の 応答も，図-3および図-4と同様の傾向を示した。

\section{(2)P1-西リブのまわし溶接部のひずみの応答特性}

図-5に示す位置に貼付したひずみゲージの応答值を基 に，横断歩道橋を利用する歩行者および横断歩道橋の下 を通過する車両によってP1-西リブのまわし溶接部付近 に発生寸る応力特性の調査を行った. 横断歩道橋を利用 する人の状態としては，1名の人が歩行および走行する ケース，3名の人が1つの集団となって歩行および走行す るケースの合計4ケースを想定して応力測定を行った.

図-6は1名の人が横断歩道橋を歩行または走行した場合 の，図-7は3名の人が1つの集団となって歩行および走行 した場合の, 図-8はトラックが横断歩道橋の下を通過し た場合の，応答ひずみをそれぞれ示す．なお，図-7(b) に示す 3 名の人が走行する場合の測定の際，3名が橋上を 走行時に1台の普通車が横断歩道橋の下を通過した.

図-6および図-7より，人が歩行する場合より走行した 方が，1名の人より3名の人の方が，応答ひずみの変動の 範囲が大きいことがわかる，図-6および図-7のケース以 外にも数回測定を行ったが，いずれの場合も，歩行より

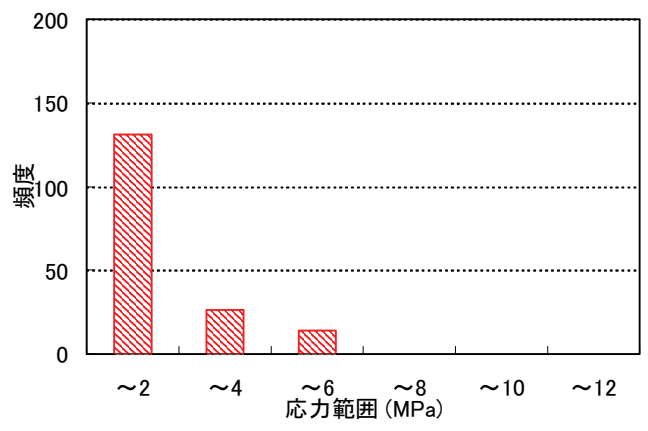

図-11 トラックの走行による応力範囲頻度分布

走行の方が，1名より3名の人の方が，応答ひずみの変動 の幅が大きくなっていた．図-8のトラック通過による応 答ひずみの変動は，図-6(a)に示す1名の人の歩行時の応 答ひずみの変動とほぼ等しくなっている. 車両の通過に よるひずみ測定についても数回行った．車両ごとにその 応答ひずみの特性はばらついたが，応答ひずみの変動の 最大值は図-8と大差なかった。

\section{(3)P1-西リブのまわし溶接部の応力範囲}

図-6〜図-8のひずみの応答值から，レインフロー法よ り，P1-西リブのまわし溶接部の応力範囲のヒストグラ ムを求めた。 その結果を図-9～図-11に示す．図-6およ び図-7のひずみの応答值と同様，1名の人より3名の人 


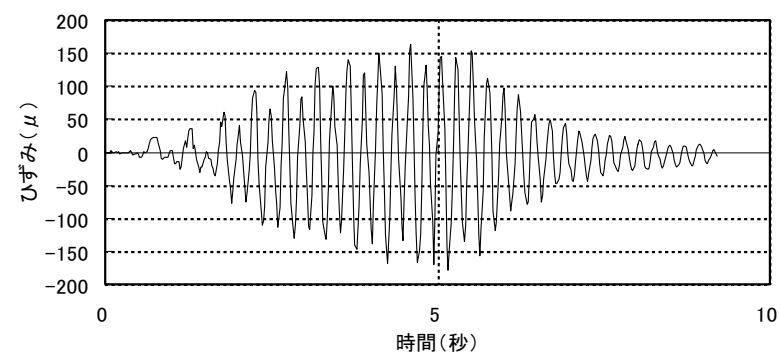

図-12 5名の歩行者がP1支柱上でジャンプ した時の応答ひずみ

の方が，歩行より走行した方が，大きな応力範囲が発生 していることがわかる，応力範囲の絶対值としては，最 大でも $12 \mathrm{MPa}$ 程度であり, 応力範囲としては大きな值と

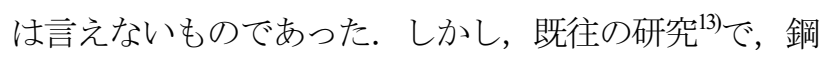
製ラーメン橋脚隅角部のはりフランジと柱の溶接が良好 でない場合, $10 \mathrm{MPa}$ 程度の小さな応力範囲であっても疲 労き裂が発生した例が報告されている．よって，P1支柱 のリブの溶接も良好ではなかったことから，12MPa程度 の応力範囲でも疲労き裂が発生したことは十分考えられ る.

\section{(4) 歩行者がジャンプした場合の応力範囲}

(3)において，最も大きな応力範囲が計測された 3 名の 人が横断歩道橋を走行して場合でも, その最大の応力範 囲は12MPa程度であった，そこで，特殊なケースとして， 5名の人が集団となって一斉にP1支柱直上でジャンプす る場合について，応答ひずみの測定し，その応答ひずみ から応力範囲を求めた．図-12に応答ひずみを, 図-13に 応力範囲と頻度のヒストグラムを示す. 図-12より, 図一 6〜図-8と比較して応答ひずみの変動範囲も大きく, そ の変動の範囲は $320 \mu$ 程度となっている，また，図-13よ り, 約70MPa と大きな応力範囲が発生していることがわ かる.

\section{6. き裂の発生メカニズムの推測}

今回，き裂の発見されたP1-東リブのまわし溶接部で は疲労破面は観察されなかったが，反対側のP1-西リブ のまわし溶接部では疲労破面が観察された.一方，5.(1) よりP1-東リブのある東面と疲労破面の観察されたP1-西 リブのある西面に車両や歩行者により発生する応力はほ ぼ等しく, P1-東リブとP1-西リブのまわし溶接部いずれ も，溶接サイズが小さい，リブ側面のすみ肉溶接部とま わし溶接部が不連続になっている等，溶接品質も大差は

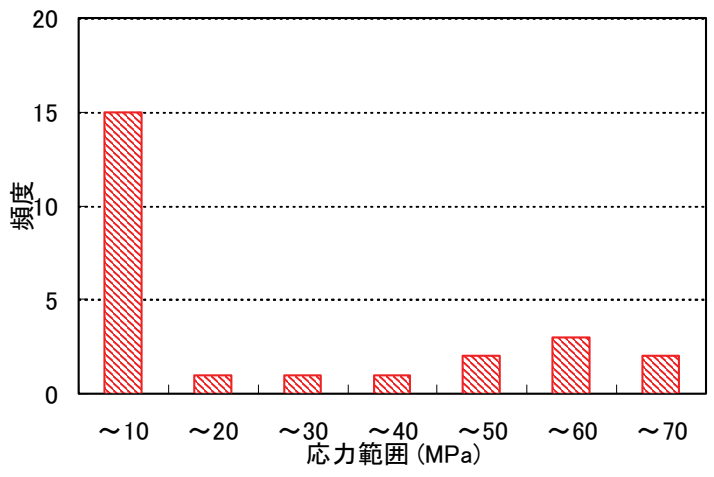

図-13５名の歩行者がP1支柱上でジャンプ した時の応力範囲頻度分布

ないものであった．また，支柱に用いられた鋼材が衝撃 に対して弱かったとしても，全くき裂の無い状態で，車 両等の衝突により支柱に衝撃が加わったことにより，支 柱の約円周の半分に及ぶような大きなき裂が発生するこ とは考えにくい.さらに，3. (2) a)で記述した通り，P1東リブ付近の破面には非常に強固な錆が付着していたた め，き裂の破面の一部しかSEM観察が出来ず，強固な錆 の状態からき裂が発生してから長期間が経過していたこ とが推測される．このことから，SEM観察を行ったP1東リブの破面についても，疲労破面が発生していたにも 関わらず，長期間の間に破面同士の擦れ等により当初の 破面がつぶれた可能性もある．また，溶接が良好でない 場合, $10 \mathrm{MPa}$ 程度の小さな応力範囲でも疲労き裂が発生 した事例も報告 ${ }^{13)}$ されている.

上記の事項，先述の 3 章 5章の調査結果より, $\mathrm{P} 1$ 支 柱に発生したき裂の発生メカニズムは，以下のように推 測できる.

1) P1-東リブのまわし溶接部およびその近傍の溶接は, 溶接サイズが小さく，まわし溶接部とリブ側面のす み肉溶接部に不連続性が見られた。 また，P1支柱に 使われた鋼材の衝撃吸収エネルギーは小さく, 衝撃 に対して非常に弱いものであった.

2) 横断歩道橋の下の道路を走行する車両, 横断歩道橋 を利用する人等により，P1-東リブのまわし溶接部 には繰返し応力が発生した. 発生する繰返し応力の 応力範囲は比較的小さかった。

3）しかし，1)で示したようにP1-東リブまわし溶接部の 溶接状態があまり良い状態でなかったため，P1-西 リブと同様，P1-東リブのまわし溶接部に疲労き裂 が発生し，進展していった。 なお，P2支柱の東西両 リブのまわし溶接部の溶接の状態は，P1支柱の東西 両リブと比較して良好であったことから，疲労き裂 は発生しなかったと考えられる.

4) 疲労き裂がある程度の長さに達していた状態で，車 


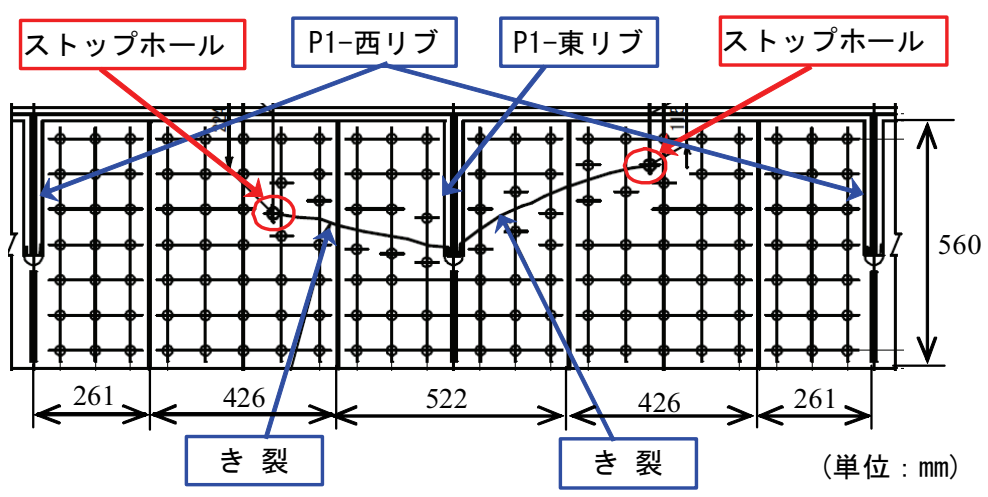

図-14 ストップホール・あて板の概要

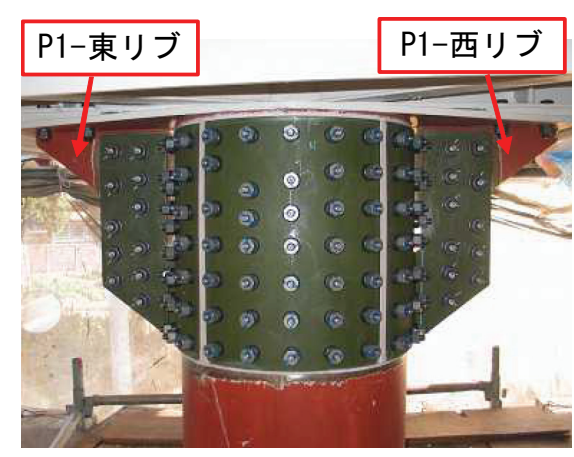

写真-14 あて板の施工状況
両の積み荷等が横断歩道橋の上部構造に衝突した.

5）支柱に使われた鋼材は，衝撃に非常に弱いものであ ったため, 車両の積み何等が上部構造に衝突したこ とにより, 疲労き裂が一気に進展して支柱の全周の 約半分に及ぶ大きなき裂損傷となった.

なお，横断歩道橋を支える2本の支柱のうち，P2支柱 ではリブのまわし溶接部付近のき裂，P1支柱で観察され た大きなき裂損傷も観察されていない.これは，3.(1)で 記述した通り，P2支柱のリブの溶接が比較的良好であっ たことが1つの要因として考えられる．鋼道路橋におい ては，溶接等の施工の不具合を原因とする疲労損傷が報 告されている ${ }^{13)}$. よって, 歩道橋においても溶接等の施 工を適切に行うことが，今回のような大きなき裂損傷を 防ぐ対策の1つである.

\section{7. き裂の補強方法}

P1支柱で発見されたき裂が，円周の約半分にも及ぶ大 きなき裂であり，さらにき裂が進展すると落橋の危険性 も考えられたことから，まず，き裂の先端にストップホ ールを設けた（図-14参照）。ストップホールを設ける に当たっては, コアを抜いた後, 磁粉探傷によりき裂先 端が確実に除去できているか確認するとともに，表面を グラインダーで平滑に仕上げを行った．そして，図-14, 写真-14に示すように, 支柱の円周方向全周に対して, あて板のみで荷重を伝達できるよう，支柱とP1-東リブ およびP1-西リブを連結するような形で板厚12mmの鋼板 によるあて板補強を行った，あて板補強では，施工性を 考慮してあて板を4分割し, 支柱内に人が入って作業が できないことから支柱の外面から高力ワンサイドボルト を用いてあて板の接合を行った. また，ストップホール の位置にもワンサイドボルトの施工を行った. なお, 最 終的には補強箇所に塗装を施した。

\section{8. まとめ}

横断歩道橋の支柱に発生した鋼管の全周の約半分にも 及ぶき裂損傷について, そのき裂損傷の発生原因調査, メカニズムの推測を行うとともに，き裂損傷に対する補 強を行った. 以下にき裂損傷に関する調査結果の概要を 示す.

1）横断歩道橋の支柱に取り付けられたリブの先端付近 のリューダス帯, 横断歩道橋の上部構造の桁の下> ランジの変形といった, 車両の積み荷等が横断歩道 橋一衝突した可能性を示唆する損傷が観察された.

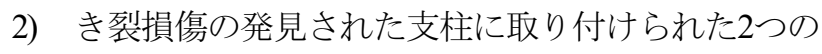
リブでは，溶接の不連続，溶接サイズが小さい等, 溶接の状態は良好でなく, き裂損傷の発見されたリ ブとは別のリブのまわし溶接部でもき裂が観察され た. それに対して，き裂損傷の発見された支柱とは

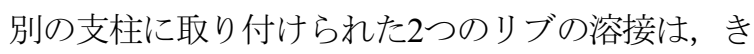
裂損傷が発見されたリブの溶接より状態が良く,ま わし溶接部にき裂も発見されなかった。

3）SEM観察の結果，き裂損傷の破面はへき開割れした 脆性破面であることが判明した，それに対し，き裂 損傷の発生した支柱のき裂損傷の存在するリブの反 対側のリブのまわし溶接部からは, ストライエーシ ヨン模様の疲労破面が観察された。 なお，き裂損傷 の破面からは疲労破面は観察されなかったが，破面 が長時間暴露されている間に, 疲労破面がつぶれた ことも考えられる.

4) き裂損傷の発生した支柱の母材の化学成分分析結果, 組織観察結果, ビッカース硬さ試験の結果, さらに 横断歩道橋の標準設計等に規定に基づいて判断する と，支柱にはSTK41が使用されていると考えられる。

5) 損傷が発生した支柱の鋼管の円周および円周直角方 向から取り出したサブサイズの試験片により, 試験 温度 $0^{\circ}$ でシャルピー衝撃試験を行った。 その結果 
支柱に使用されていた鋼管はシャルピー吸収エネル ギーが低くかつ脆性破面率も100\%に近く，非常に 衝撃に弱いものであることがわかった.

6) 歩道橋の下を通過する車両，1名もしくは3名の人が 横断歩道橋を歩行もしくは走行する場合について， 支柱に取り付けられたリブのまわし溶接部付近のひ ずみの測定し，そこから応力範囲およびその頻度を 求めたが，得られた応力範囲は最大でも $12 \mathrm{MPa}$ 程度 と大きなものではなかった. なお，特異なケースと して，5名の人が集団となって一斉にき裂損傷が発 生した支柱上でジャンプした時に得られる応力範囲

は，70MPa程度の大きなものであった。

上記の調査結果, さらに既往の研究で溶接が良好でな い場合には10MPa程度の小さな応力範囲でも疲労き裂が 発生した事例が報告されていることから，き裂損傷の発 生原因, メカニズムとして以下のことが推測される.

1) 通常の横断歩道橋の使用条件下で発生する応力範囲 は大きいとは言えないが，溶接品質が良くないこと から，支柱に取り付けられたリブのまわし溶接部か ら疲労き裂が発生および進展し, 疲労き裂がある程 度の長さに至った.

2) その状態で, 車両の荷物等が歩道橋の上部構造に衝 突した. 支柱に使われている鋼管が衝撃に対して非 常に弱かったことから, 衝突による衝撃力で一気に 支柱の全周の約半分に達するようなき裂が発生した. なお，き裂損傷の補強法としては，あて板補強を実施 し, あて板で荷重を伝達できるような補強を行った。

謝辞 : 本論文を作成するに当たり, 茨城県土木部道路維 持課および竜ヶ崎土木事務所の関係各位，茨城大学工学
部技術職員 田名部菊次郎氏, (株)東京鐵骨橋梁 柳沼安俊氏にご協力いただきました. ここに深くお礼申 し上げます。

\section{参考文献}

1) 日本道路協会 : 鋼橋の疲労, 1997 .

2) http://iiw-wg5.cv.titech.ac.jp/, IIW-XIII-WG5, Repair of fatigue loaded welded structures.

3) Miki, C. and Konishi, T.: Retrofit Engineering for Steel Bridge Structures in Japan, A-0673, IABSE SYMPOSIUM, WEIMAR, 2007.

4) 三木千壽：造る時代から守る時代へ一技術者に求め るモノ一, (財) 首都高速道路技術センター技術講習 会資料， 2008.

5) 岡下勝彦, 大南亮一, 道場康二, 山本晃久, 冨松実, 丹治康行, 三木千壽 : 兵庫県南部地震による神戸港 港湾幹線道路 P75 橋脚隅角部におけるき裂損傷の原 因調查・検討, 土木学会論文集, No.591/I-43, pp.243-261, 1998.

6) 国土交通省道路局企画課監修: 第七次改訂 道路技術 通達集一基準の変遷と通達一, ぎょうせい, 2006.

7) 国土交通省道路局企画課監修: 道路統計年報 2008 年 版, 全国道路利用者会議, 2008.

8) 日本道路協会：横断歩道橋設計（参考設計）指針解 説, 1966.

9）日本道路協会：立体横断施設技術基準 - 同解説, 1979.

10）日本道路協会：横断歩道橋設計図集，1966.

11) 日本道路協会 : 土木構造物標準設計 V (横断歩道 橋) , 1967.

12）日本道路協会 : 横断歩道橋便覧, 1969.

13) 三木千壽, 平林泰明 : 施工の不具合を原因とする疲 労損傷, 土木学会論文集 A, Vol.63, No.3, pp.518532, 2007.

(2008. 10. 15受付)

\title{
CAUSE IDENTIFICATION OF THE FRACTURE IN STEEL PIPE COLUMN OF A PEDESTRIAN BRIDGE AND ITS RETROFITTING
}

\author{
Chitoshi MIKI, Kiyoshi ONO, Koichi YOKOYAMA and Takao HARADA
}

A Serious fracture that extended halfway through the circumference of a steel pipe column was discovered in a pedestrian bridge across a prefectural road. A lot of pedestrian bridges have been designed and constructed according to the standard specifications. Therefore, there is a possibility that pedestrian bridges whose structural details are the same as those of fractured pedestrian bridges in this paper may exist. It is very important to identify the cause of the fracture for preventing the same failure mode.

In order to identify the cause of the fracture, observation of crack surface, SEM observation, material property tests, measurement of strain and calculating histogram of the stress range and the frequency were carried out. Moreover, the fractured steel pipe column of the pedestrian bridge was retrofitted by applying bolted splice rings and plates. 